\title{
Predictive Capacity of Psychopathological Symptoms for Spanish Adolescents' Future Expectations
}

\author{
Laura Verdugo, Yolanda Sánchez-Sandoval \\ Department of Psychology, University of Cádiz, Cádiz, Spain \\ Email: laura.verdugo@uca.es, yolanda.sanchez@uca.es
}

How to cite this paper: Verdugo, L. and Sánchez-Sandoval, Y. (2018) Predictive Capacity of Psychopathological Symptoms for Spanish Adolescents' Future Expectations. Open Access Library Journal, 5: e4546. https://doi.org/10.4236/oalib.1104546

Received: March 26, 2018

Accepted: April 26, 2018

Published: April 29, 2018

Copyright $\odot 2018$ by authors and Open Access Library Inc.

This work is licensed under the Creative Commons Attribution International License (CC BY 4.0).

http://creativecommons.org/licenses/by/4.0/

\begin{abstract}
This study examines the association between psychopathological problems and future expectations in Spanish early adolescents. Participants were 781 students $(48.5 \%$ female) from 11 secondary schools, aged $11-15$ years $(M=$ 12.37, $S D=0.66)$. The students were of middle and middle-low socioeconomic status. Participants with higher levels of psychopathological problems (emotional and behavioral problems) had lower future expectations. Regression analysis confirmed that certain psychopathological dimensions (anxious/depressed, delinquent behavior, thought problems, social problems) predict some variability of future expectations in early adolescence. The main contribution of this research is to further our comprehension of the development of adolescents' future expectations and the way in which psychopathological problems have an impact on such development. Future expectations are an important protective factor for healthy development in adolescence, as thinking about the future motivates everyday behavior and influences choices, decisions, and future activities. This paper emphasizes the need for preventive intervention, and at early ages, on cognitive processes related to the future temporal perspective in cases of psychopathological problems.
\end{abstract}

\section{Subject Areas}

Psychology, Sociology

\section{Keywords}

Future Expectations, Psychopathological Problems, Internalizing Problems, Externalizing Problems, Early Adolescence

\section{Introduction}

Adolescents' future expectations are bound to the cultural, economic, and political 
context in which they live. In the last decade, national youth unemployment rates increased in Southern European countries. This could trigger a decrease in personal future expectations. Future expectations have been defined as beliefs about the probability that a specific event will occur in the future [1], and they are important predictors of future behavior and development [2]. Previous research has shown the association between future expectations and higher engagement, persistence to complete tasks, and better academic performance [3]. Future expectations are particularly relevant to people in a transitional period of their development, as a way to prepare for the future [4], and are conceived as a positive path to adulthood [5].

Although works about this are not abundant in the literature, some studies begin to analyze the relation between future expectations and the presence of psychopathology during adolescence. Optimism and hope for a positive future can serve as protective factors [6] and are also related to resilience, social adjustment, and well-being. Optimism, consistently linked to future orientation, has been associated negatively with depressive symptoms and hopelessness among adolescents [7]. Future-oriented individuals probably consider the consequences of their present actions when making decisions, and people with a more optimistic view of their future are generally more sensitive to the future consequences of their current behavior [8]. As a result, individuals who express higher levels of orientation towards the future are less likely to get involved in behavior problems because these behaviors may be risking their future. Nurmi (1991) [9] pointed out that adolescents who are less oriented towards the future could present behavior problems such as delinquency, problems at school or drug use.

On another hand, a particularly important aspect in the formation of adolescents' future expectations is the possible selves. The theory of possible selves [10] is a useful way to examine the importance of the optimistic future and its impact on mental health. This theory suggests that adolescents' mental health is influenced by their capacity to imagine themselves as different possible selves in the future. This capacity will facilitate the formation of goals and personal dreams, positively influencing the optimistic future and linking this cognitive process to better mental health in the present. For instance, in a study with a sample of Chinese children and adolescents affected by HIV/AIDS, future orientation fully mediated the relationship between traumatic events and their mental health (i.e., depression, loneliness, self-esteem) [11]. In the same vein, other authors [12] [13] examined a sample of young people living in foster care and found that the more future-oriented youths had significantly lower levels of internalizing symptomatology (such as anxiety or depressive symptoms) as well as fewer externalizing problems (such as delinquency or aggression). In addition, studies such as those of Robbins and Bryan (2004) [14] found that future orientation was a protective factor for adolescents who had a high level of impulsivity. Boys and girls with high impulsiveness and negative future orientation showed the highest levels of risk behavior.

Although early adolescents tend to have positive future expectations [15], the 
current research examines whether the presence of psychopathology could be a risk factor for a positive view to the future. The study aims to: 1) analyze whether the future expectations of adolescents with psychopathological problems differ from those of others without problems (categorical model of mental disorder: clinical vs. normative group); 2) analyze the predictive capacity of psychopathological problems on adolescents' future expectations (dimensional model).

In relation to these overall aims, we tested the following hypotheses: 1) participants with higher levels of psychopathological problems (clinical range) have lower future expectations; 2) certain psychopathological dimensions predict part of the variability of the future expectations in early adolescence.

\section{Method}

The sample was composed of 781 adolescents from 11 secondary schools $\left(1^{\text {st }}\right.$ grade of Secondary Education in Spain). They were schools with middle and middle-low socioeconomic status. Of all these participants, 402 were male $(51.5 \%)$ and 379 were female (48.5\%), aged between 11 and 15 . The mean age was $12.37(S D=0.66)$.

\subsection{Procedure}

We contacted the selected school headmasters and requested their participation in the study. After receiving the consent of the school headmasters and families, we visited the classrooms. The research project was accepted by the Doctoral Committee of the University of Cádiz (Spain). Permission was obtained from the local educational authorities and from the School Council in each school. Informed consent was obtained from all individual participants included in the study. Student participation was anonymous and voluntary. Questionnaire administration was completed in whole class groups. Cases with missing data were previously omitted.

\subsection{Measures}

Adolescents Future Expectations Scale (EEFA; Sánchez-Sandoval \& Verdugo, 2016) [15] (Appendix I). This 14-item self-report scale determines what adolescents think about their future. Each item is rated on a five-point Likert scale ranging from 1 ( $I$ am sure that will not happen) to 5 ( $I$ am sure that will happen). It includes four dimensions: Economic expectations (job prospects and acquisition of material resources; e.g., "I will find a job"), Academic expectations (expected level of study; e.g., "I will complete Secondary Education"), Personal well-being expectations (possibilities of developing social relations and issues related to health and safety; e.g., "I will be confident"), and Family expectations (possibilities of forming a stable family, having children, and so on; e.g., "I will have children"). Higher scores indicate more positive expectations about the events occurring in the future. Global scale and subscales showed acceptable reliability (Cronbach alpha): Global scale, $\alpha=0.86$; Economic expectations, $\alpha=0.79$; Academic expectations, $\alpha=0.81$; Personal well-being expectations, $\alpha=0.68$; and 
Family expectations, $\alpha=0.70$.

Youth Self Report (YSR; Achenbach, 1991) [16] (Appendix II). This is a self-report that assesses emotional and behavioral problems. There are 112 items on which participants rate whether or not they have felt this way in the past six months $(0=$ not true, $1=$ a little true and $2=$ very true $)$. The items are grouped into various scales or "narrowband" syndromes (anxious/depressed, somatic complaints, social problems, delinquent behavior, aggressive behavior, attention problems, thought problems) and two second-order factors or "broadband" syndromes (internalizing and externalizing problems). The reliability for the "narrowband" syndromes in our study ranged from $\alpha=0.65$ to $\alpha=0.84$, and for the "broadband" syndromes, it was $\alpha=0.87$.

\subsection{Data Analysis}

Data analysis was carried out using the Statistical Program for the Social Sciences PASW Statistics for Windows (version 21). We present descriptive results and the correlations between the variables. Spearman's non-parametric rho test was used to perform bivariate correlation analyses because the data did not follow a normal distribution. To analyze the differences by groups, the non-parametric Kruskal-Wallis and Mann-Whitney tests were used. Finally, a regression analysis model (stepwise method) was performed.

\section{Results}

Table 1 shows the descriptive statistics (range, means, and standard deviations) of the variables of the study.

Table 1. Descriptive statistics of the main variables of the study.

\begin{tabular}{cccccc}
\hline & & Minimum & Maximum & Mean & $S D$ \\
\hline & Global scale & 1.00 & 5.00 & 4.25 & 0.52 \\
Economic Expectations & 1.00 & 5.00 & 4.19 & 0.61 \\
Future Expectations & Academic Expectations & 1.00 & 5.00 & 4.17 & 0.92 \\
& Well-being Expectations & 1.00 & 5.00 & 4.38 & 0.60 \\
& Family Expectations & 1.00 & 5.00 & 4.30 & 0.67 \\
\hline \multirow{2}{*}{$\begin{array}{c}\text { Global scale } \\
\text { Emotional and }\end{array}$} & 0.02 & 1.49 & 0.36 & 0.22 \\
behavioral & Internalizing problems & 0.00 & 1.63 & 0.39 & 0.28 \\
& Externalizing problems & 0.00 & 1.58 & 0.44 & 0.29 \\
& Anxious/depressed & 0.00 & 2.00 & 0.25 & 0.33 \\
& Delinquent behavior & 0.00 & 1.71 & 0.23 & 0.25 \\
& Aggressive behavior & 0.00 & 2.00 & 0.73 & 0.46 \\
& Somatic complaints & 0.00 & 1.90 & 0.41 & 0.31 \\
& Thought problems & 0.00 & 2.00 & 0.29 & 0.35 \\
& Social problems & 0.00 & 1.86 & 0.51 & 0.37 \\
& Attention problems & 0.00 & 1.70 & 0.36 & 0.30 \\
\hline & & & & \\
\hline
\end{tabular}


In addition to these quantitative scores, for each dimension of the $Y S R$, participants were classified into two groups according to whether they fell within the clinical group (manifesting more problems) or in the normative group (presenting fewer problems). Adolescents in the clinical group scored one Standard Deviation above the mean. In our case, this included about $15 \%$ of the participants ( $N=118$ in the clinical group and $N=663$ in the normative group).

\subsection{Correlations between Future Expectations (EEFA) and Emotional and Behavioral Problems (YSR)}

The correlations between the mean scores on the YSR and the Future Expectations dimensions are shown in Table 2.

Results showed a significant negative correlation between the total YSR score and all its subscales and the global score of Future Expectations: the more emotional and behavioral problems, the lower were future expectations. We also found statistically significant negative correlations between the YSR scores and the subscales of Economic/Work, Academic, and Personal Well-being expectations. The correlations with the subscale of Family expectations were somewhat lower, but still, the more problems, the lower the Family expectations.

Regarding Internalizing problems, the highest correlation was with Personal Well-being expectations $(r=-0.33, p<0.001)$. The score of Externalizing problems had the highest correlation with Academic expectations $(r=-0.32, p<0.001)$.

The highest correlations were the following: Global expectations and Personal Well-being expectations with Anxious/Depressed $(r=-0.36, p<0.001$ and $r=$ $-0.35, p<0.001$, respectively), Academic expectations with Delinquent behavior $(r=-0.40 ; p<0.001)$, and Personal Well-being expectations with Social Problems $(r=-0.28 ; p<0.001)$.

Table 2. Spearman correlations between the YSR and the future expectations dimensions.

\begin{tabular}{|c|c|c|c|c|c|}
\hline & $\begin{array}{l}\text { EEFA } \\
\text { Global }\end{array}$ & $\begin{array}{c}\text { Economic } \\
\text { Expectations }\end{array}$ & $\begin{array}{c}\text { Academic } \\
\text { Expectations }\end{array}$ & $\begin{array}{l}\text { Well-being } \\
\text { Expectations }\end{array}$ & $\begin{array}{c}\text { Family } \\
\text { Expectations }\end{array}$ \\
\hline YSR Global & $-0.32^{* * *}$ & $-0.23^{* * *}$ & $-0.30^{\star * *}$ & $-0.30^{\star * *}$ & $-0.12^{\star \star}$ \\
\hline Internalizing problems & $-0.32^{* * *}$ & $-0.24^{\star * *}$ & $-0.23^{\star * *}$ & $-0.33^{* * *}$ & $-0.18^{\star * *}$ \\
\hline Externalizing problems & $-0.32^{* * *}$ & $-0.24^{\star * *}$ & $-0.32^{\star * *}$ & $-0.25^{\star * *}$ & $-0.08^{*}$ \\
\hline Anxious/depressed & $-0.36^{\star * *}$ & $-0.26^{\star * *}$ & $-0.26^{\star * *}$ & $-0.35^{\star * *}$ & $-0.20^{\star * *}$ \\
\hline Delinquent behavior & $-0.34^{* * *}$ & $-0.22^{\star * *}$ & $-0.40^{* * *}$ & $-0.25^{\star * *}$ & $-0.08^{*}$ \\
\hline Aggressive behavior & $-0.21^{\star * *}$ & $-0.17^{\star * *}$ & $-0.21^{\star * *}$ & $-0.17^{\star * *}$ & -0.03 \\
\hline Somatic complaints & $-0.20^{\star * *}$ & $-0.14^{\star * *}$ & $-0.20^{\star * *}$ & $-0.21^{\star * *}$ & -0.05 \\
\hline Thought problems & $-0.14^{\star * *}$ & -0.05 & $-0.14^{\star * *}$ & $-0.21^{\star * *}$ & -0.03 \\
\hline Social problems & $-0.27^{\star * *}$ & $-0.21^{\star \star *}$ & $-0.17^{\star * *}$ & $-0.28^{\star * *}$ & $-0.18^{\star * *}$ \\
\hline Attention problems & $-0.31^{\star * *}$ & $-0.24^{\star * *}$ & $-0.28^{\star * *}$ & $-0.26^{* * *}$ & $-0.11^{\star *}$ \\
\hline
\end{tabular}




\subsection{Comparison of Future Expectations in the Clinical and Normative Groups}

Based on the YSR scores, the participants were divided into two groups (clinical score vs. non-clinical). Fifteen percent of the subjects with the highest scores in the assessed problems were classified in the clinical groups.

Regarding the global scale of the YSR, adolescents with clinical range scores had lower global expectations $(\mathrm{U}=26,337.500, Z=-5.666, p<0.001)$, Economic/work $(U=31,696.000, Z=-3.306, p<0.01)$, Academic $(U=25,368.500, Z=$ -6.255, $p<0.001)$, and Personal Well-being expectations $(U=29,195.500, Z=$ $-4.490, p<0.001$ ), than the normative group (Figure 1). Differences in Family expectations were nonsignificant.

Regarding the presence of externalizing problems, we found differences in the global scale and in all dimensions except for Family expectations (Figure 2). Thus, differences were found in Global Expectations $(U=29,638.000, \mathrm{Z}=$ -5.309, $p<0.001)$, and in Economic/Work $(U=34,212.000, \mathrm{Z}=-3.369, p<$ 0.01 ), Academic $(U=27,469.000, Z=-6.400, p<0.001)$, and Personal Well-being expectations $(U=31,622.000, \mathrm{Z}=-4.553, p<0.001$ ). The clinical group participants indicated lower expectations than the normative group.

Regarding the presence of internalizing problems (Figure 3), we found that

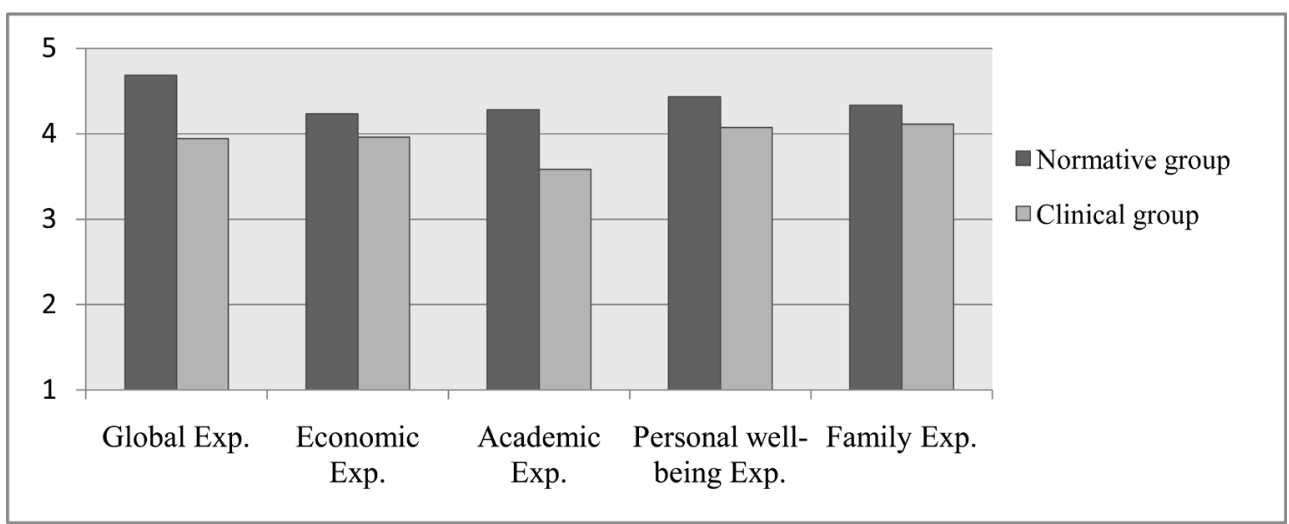

Figure 1. Future expectations according to YSR total scores (clinical and normative groups).

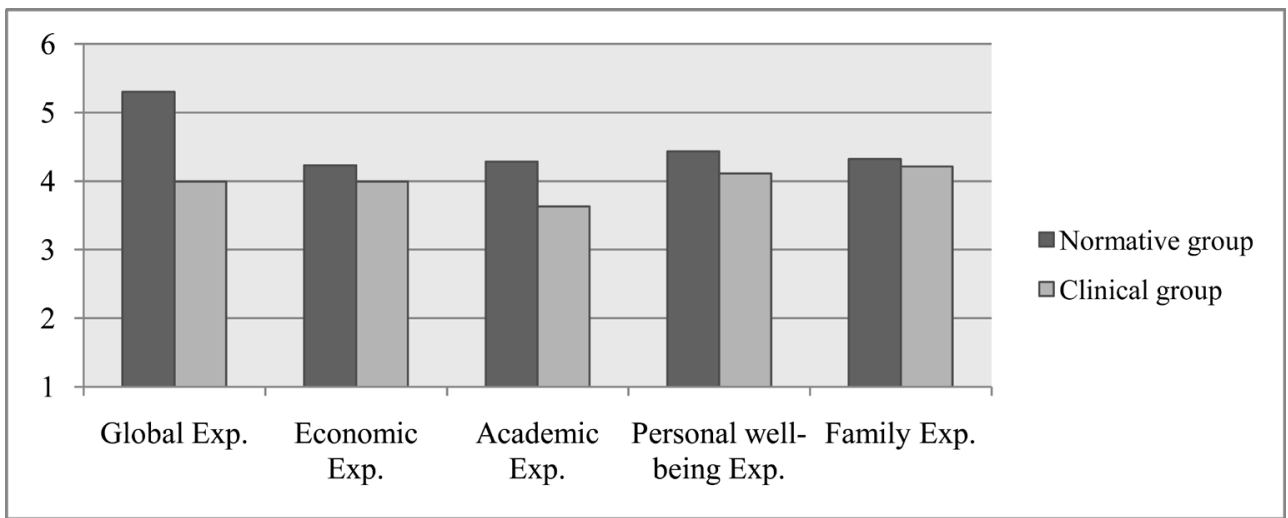

Figure 2. Future expectations according to YSR externalizing problems (clinical and normative groups). 


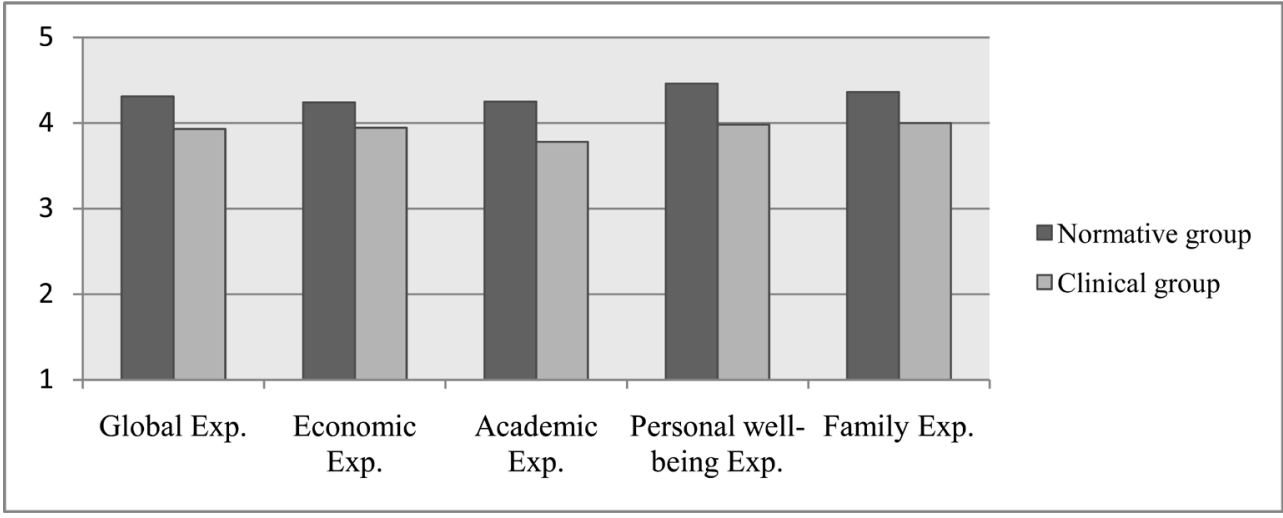

Figure 3. Future expectations according to YSR internalizing problems (clinical and normative groups).

Table 3. Summary of the regression analysis of variables predicting global future expectations.

\begin{tabular}{ccccccc}
\hline Variables & $R$ & $R^{2}$ & Corrected $R^{2}$ & SE & $\beta$ & $p$ \\
\hline Anxious/depressed & 0.39 & 0.15 & 0.15 & 0.48 & -0.30 & 0.000 \\
Delinquent behavior & 0.42 & 0.17 & 0.17 & 0.48 & -0.19 & 0.000 \\
Thought problems & 0.43 & 0.18 & 0.18 & 0.47 & -0.14 & 0.000 \\
Social problems & 0.44 & 0.19 & 0.18 & 0.47 & -0.09 & 0.000 \\
\hline
\end{tabular}

participants in the clinical group had lower future expectations, both global ( $U=$ 27,344.500, $Z=-6.290, p<0.001)$, and in its four dimensions: Economic/Work ( $U=32,784.500, Z=-3.983, p<0.001)$, Academic $(U=31,871.500, Z=-4.468$, $p<0.001)$, Personal Well-being $(U=25,785.500, Z=-7.101, p<0.001)$, and Family $(U=32,492.000, Z=-4.168, p<0.001)$.

\subsection{Predictive Capacity of the YSR for Global Future Expectations}

The regression analysis (dependent variable: EEFA; independent variables: YSR subscales) showed that the coefficient of determination $\left(R^{2}\right)$ indicates that the included variables explained $19.3 \%$ of global future expectations, $F(4,776)=$ 46.527, $p<0.001$. That percentage is explained by the adolescents' depression/anxiety, criminal misconduct, thinking problems, and relationship problems. These future expectations increase along as some of their psychopathological problems decrease (Table 3).

\section{Discussion}

In this work, we analyzed the future expectations and emotional and behavioral problems of early adolescents during the current financial crisis. A first conclusion is that Spanish adolescents with higher levels of psychopathological problems had lower future expectations ( $1^{\text {st }}$ hypothesis), as prior researchers have shown in other countries [14] [15] [16] [17]. The direction of the relations between these two variables is not clear. Chen and Vazsonyi (2013) [18] provide 
evidence that the future orientation of the teenagers is negatively associated with behavior problems. Youngsters with pessimistic future expectations are more vulnerable to engage in behavioral problems [19].

Adolescent psychopathology can be a risk factor for a positive view to the future: our results show that certain psychopathological dimensions (anxious/depressed, delinquent behavior, thought problems, social problems) predict some variability of the future expectations in early adolescence ( $2^{\text {nd }}$ hypothesis). Van Beek, Berghuis, Kerkhof, and Beekman (2011) [20] have reported that suicidal patients lack the ability to envision a positive future. A high tendency toward positive future thinking seems to protect people from suicide.

This work has some clinical implications. Future expectations are an important protective factor for healthy development in adolescence because thinking about the future motivates everyday behavior and influences choices, decisions, and future activities. This is relevant now, when depression is increasing among young people due to the lack of expectations, coinciding with the economic crisis [21].

Other authors show the key role of future expectations as a motor and drive for achievement and personal adjustment [22]. This paper stresses the need for preventive intervention, and at early ages, on cognitive processes related to the future temporal perspective in cases of psychopathological problems. This type of intervention is expected to lead to adjustment and future psychological development (e.g., preventing higher levels of depression and suicide).

Another clinical implication is that improving positive future expectations will increase adherence to a psychological treatment program during adolescence. Individuals oriented toward the present tend to develop short-term goals, focusing on immediate gratification; forward-looking people develop more skills of planning and are focused on long-term goals [23]. The latter are, therefore, more protected against risk behavior; that is, they anticipate the obstacles they may encounter on the pathway to success [24].

The main limitation of this study is the use of self-reports and questionnaires as the only method of data collection. However, the use of questionnaires has obvious advantages, as validated and standardized tests allow for the comparison between subjects.

\section{Conclusions}

Taking into account the results obtained in this study, it is necessary to point out the important role of future expectations when it comes to preventing future problems of personal adjustment in adolescence, mainly emotional and behavioral problems.

Those adolescents who show high future expectations and have the skills to plan and set goals tend to postpone their rewards over time and to correctly guide their behavior to achieve them. However, there are boys and girls who, instead of setting long-term goals, try to satisfy immediate goals, thus acting in the 
present without thinking about the possible consequences that their actions may have in the future. Examples of this can be observed in acts of delinquency, drug use, early pregnancy, school dropout, among others. Many of the adolescents who suffer these problems are in situation of disadvantage and need even more of a specific intervention.

\section{References}

[1] Oettingen, G. and Mayer, D. (2002) The Motivating Function of Thinking about the Future: Expectations versus Fantasies. Journal of Personality and Social Psychology, 83, 1198-1212. https://doi.org/10.1037/0022-3514.83.5.1198

[2] Sipsma, H.L., Ickovics, J.R., Lin, H. and Kershaw, T.S. (2012) Future Expectations among Adolescents: A Latent Class Analysis. American Journal of Community Psychology, 50, 169-181. https://doi.org/10.1007/s10464-011-9487-1

[3] Froehlich, D.E., Beausaert, S.A. and Segers, M.S. (2015) Great Expectations: The Relationship between Future Time Perspective, Learning from Others, and Employability. Vocations and Learning, 8, 213-227.

https://doi.org/10.1007/s12186-015-9131-6

[4] Seginer, R. (2008) Future Orientation in Times of Threat and Challenge: How Resilient Adolescents Construct Their Future. International Journal of Behavioral Medicine, 32, 272-282. https://doi.org/10.1177/0165025408090970

[5] Snyder, C.R., Rand, K.L. and Sigmon, D.R. (2002) Hope Theory: A Member of the Positive Psychology Family. In: Snyder, C.R. and Lopez, S.J., Eds., Handbook of Positive Psychology, Oxford University Press, New York, 231-243.

[6] Sulimani-Aidan, Y. and Benbenishty, R. (2011) Future Expectations of Adolescents in Residential Care in Israel. Children and Youth Services Review, 33, 1134-1141. https://doi.org/10.1016/j.childyouth.2011.02.006

[7] Smokowski, P.R., Evans, C.B.R., Cotter, K.L. and Webber, K.C. (2013) Ethnic Identity and Mental Health in American Indian Youth: Examining Mediation Pathways through Self-Esteem and Future Optimism. Journal of Youth and Adolescence, 43, 343-355. https://doi.org/10.1007/s10964-013-9992-7

[8] Routledge, C. and Arndt, J. (2005) Time and Terror: Managing Temporal Consciousness and the Awareness of Mortality. In: Strathman, A. and Joireman, J., Eds., Understanding Behavior in the Context of Time, Erlbaum, Mahwah, NJ, 59-84.

[9] Nurmi, J.E. (1991) How Do Adolescents See Their Future? A Review of the Development of Future Orientation and Planning. Developmental Review, 11, 1-59. https://doi.org/10.1016/0273-2297(91)90002-6

[10] Markus, H. and Nurius, P. (1986) Possible Selves. American Psychologist, 41, 954-969. https://doi.org/10.1037/0003-066X.41.9.954

[11] Zhang, J., Zhao, G., Li, X., Hong, Y., Fang, X., Barnett, D., Zhang, L., et al. (2009) Positive Future Orientation as a Mediator between Traumatic Events and Mental Health among Children Affected by HIV/AIDS in Rural China. AIDS Care, 21, 1508-1516. https://doi.org/10.1080/09540120902923048

[12] Cabrera, P., Auslander, W. and Polgar, M. (2009) Future Orientation of Adolescents in Foster Care: Relationship to Trauma, Mental Health, and HIV Risk Behaviors. Journal of Child and Adolescent Trauma, 2, 271-286. https://doi.org/10.1080/19361520903317311

[13] Polgar, M. and Auslander, W. (2009) HIV Prevention for Youths in Foster Care: Understanding Future Orientation and Intended Risk Behaviors. Journal of 
HIV/AIDS and Social Services, 8, 397-413.

https://doi.org/10.1080/15381500903417646

[14] Robbins, R.N. and Bryan, A. (2004) Relationships between Future Orientation, Impulsive Sensation Seeking, and Risk Behavior among Adjudicated Adolescents. Journal of Adolescent Research, 19, 428-445. https://doi.org/10.1177/0743558403258860

[15] Sánchez-Sandoval, Y. and Verdugo, L. (2016) Desarrollo y validación de la Escala de Expectativas de Futuro en la Adolescencia (EEFA). [Development and Validation of the Adolescent Future Expectations Scale (EEFA).] Anales de Psicología, 32, 545-554. https://doi.org/10.6018/analesps.32.2.205661

[16] Achenbach, T.M. (1991) The Child Behavior Checklist: Manual for the Teacher's Report Form. University of Vermont, Burlington, VT.

[17] Bolland, J.M. (2003) Hopelessness and Risk Behaviour among Adolescents Living in High-Poverty Inner-City Neighborhoods. Journal of Adolescence, 26, 145-158. https://doi.org/10.1016/S0140-1971(02)00136-7

[18] Chen, P. and Vazsonyi, A.T. (2013) Future Orientation, School Contexts, and Problem Behaviors: A Multilevel Study. Journal of Youth and Adolescence, 42, 67-81. https://doi.org/10.1007/s10964-012-9785-4

[19] Jessor, R., Turbin, M.S., Costa, F.M., Dong, Q., Zhang, H. and Wang, C. (2003) Adolescent Problem Behavior in China and the United States: A Cross-National Study of Psychosocial Protective Factors. Journal of Research on Adolescence, 13, 329-360. https://doi.org/10.1111/1532-7795.1303004

[20] Van Beek, W., Berghuis, H., Kerkhof, A. and Beekman, A. (2011) Time Perspective, Personality and Psychopathology: Zimbardo's Time Perspective Inventory in Psychiatry. Time \& Society, 20, 364-374. https://doi.org/10.1177/0961463X10373960

[21] Rius, M. (2015) La falta de expectativas aumenta la depresión entre los jóvenes. [The Lack of Expectations Increases Depression in Youths.] La Vanguardia. http://www.lavanguardia.com/vida/20150406/54429687811/falta-expectativas-depre sion jovenes.html

[22] Verdugo, L., Freire, T. and Sánchez-Sandoval, Y. (2018) Understanding the Connections between Self-Perceptions and Future Expectations: A Study with Spanish and Portuguese Early Adolescents. Revista de Psicodidáctica, 23, 39-47. https://doi.org/10.1016/j.psicoe.2017.07.001

[23] Monahan, K. C., Steinberg, L., Cauffman, E. and Mulvey, E.P. (2009) Trajectories of Antisocial Behavior and Psychosocial maturity from adolescence to young adulthood. Developmental Psychology, 45, 1654-1668. https://doi.org/10.1037/a0015862

[24] Zimbardo, P., \& Boyd, J. (2010). The time paradox: Using the new psychology of time to your advantage. London: Rider. 


\section{APPENDIX I}

Code Age: Boy Girl

EEFA

We would like to know how you think your future will be. Imagine yourself in a time, when few years pass, and answer the following questions.

How likely do you think the following things happen to you? Mark with an X.

I am sure that will It is difficult to
Items




\section{APPENDIX II}

A continuación se enumeran diversas frases que describen algunas conductas. En cada frase describe lo que a ti te pasa ahora o durante los últimos 6 meses rodeando con un círculo el 2 si lo que dice es muy cierto o te ocurre frecuentemente, el 1 si la frase es algo cierta o te sucede a veces, y el 0 si no es cierta.

$0=$ No es verdad $\quad 1=$ Algo verdadero o verdad a medias $\quad 2=$ Muy verdadero o frecuentemente es verdad

$\begin{array}{llll}0 & 1 & 2 & 1 . \text { Me comporto como si tuviera menos edad de la que tengo }\end{array}$

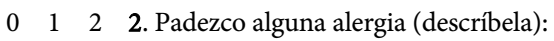

$\begin{array}{llll}0 & 1 & 2 & 3\end{array}$. Discuto mucho

$\begin{array}{llll}0 & 1 & 2 & 4\end{array}$. Tengo asma

$\begin{array}{llll}0 & 1 & 2 & 5\end{array}$. Me comporto como las personas del otro sexo

$\begin{array}{llll}0 & 1 & 2 & 6 . \text { Me gustan los animales }\end{array}$

$\begin{array}{llll}0 & 1 & 2 & 7 . \text { Suelo fanfarronear }\end{array}$

$\begin{array}{llll}0 & 1 & 2 & 8\end{array}$. Tengo problemas para concentrarme o mantener la atención

$\begin{array}{llll}0 & 1 & 2 & 9\end{array}$. No puedo apartar la mente de ciertos pensamientos (descríbelos):

$\begin{array}{llll}0 & 1 & 2 & 10\end{array}$. Tengo dificultad para mantenerme sentado

$\begin{array}{llll}0 & 1 & 2 & 11 .\end{array}$. Dependo demasiado de las personas mayores

$\begin{array}{llll}0 & 1 & 2 & 12 . \\ 0 \text { Me siento solo }\end{array}$

$\begin{array}{llll}0 & 1 & 2 & 13\end{array}$. Me siento confuso o incapaz de comprender las cosas

$\begin{array}{llll}0 & 1 & 2 & 14\end{array}$. Lloro mucho

$\begin{array}{llll}0 & 1 & 2 & 15\end{array}$. Soy bastante honrado

$\begin{array}{llll}0 & 1 & 2 & 16 . \text { Soy tacaño con los demás }\end{array}$

$\begin{array}{llll}0 & 1 & 2 & 17 . \\ 17\end{array}$

012 18. Deliberadamente he tratado de hacerme daño a mí mismo o suicidarme

$\begin{array}{llll}0 & 1 & 2 & 19 . \\ 0\end{array}$

$\begin{array}{llll}0 & 1 & 2 & 20 .\end{array}$

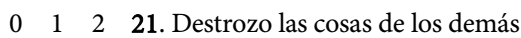

$\begin{array}{llll}0 & 1 & 2 & 22 . \\ & 2 \text { Desobedezco a mis padres }\end{array}$

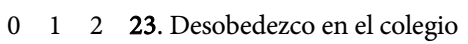

$\begin{array}{llll}0 & 1 & 2 & 24 . \text { Soy mal comedor }\end{array}$

$\begin{array}{llll}0 & 1 & 2 & 25\end{array}$. No me relaciono con los demás

$\begin{array}{llll}0 & 1 & 2 & 26\end{array}$. No me siento culpable cuando hago algo que está mal

$\begin{array}{llll}0 & 1 & 2 & 27 . \\ \end{array}$

$\begin{array}{llll}0 & 1 & 28 & 28 \\ & \text { Estoy dispuesto a ayudar a los demás cuando lo necesitan }\end{array}$

012 29. Le tengo miedo a algunos animales, situaciones o lugares, aparte del colegio (descríbelas):

$\begin{array}{llll}0 & 1 & 2 & 30 .\end{array}$. Tengo miedo de ir al colegio $\begin{array}{llll}0 & 1 & 2 & 31 . \text { Tengo miedo de pensar o hacer algo malo }\end{array}$

$\begin{array}{llll}0 & 1 & 2 & 32 .\end{array}$ Pienso que tengo que ser perfecto

$\begin{array}{llll}0 & 1 & 2 & 33 . \\ & 33 & \text { Pienso que nadie me quiere }\end{array}$

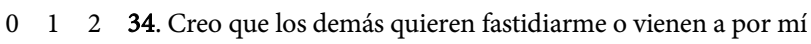

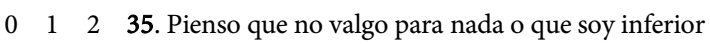

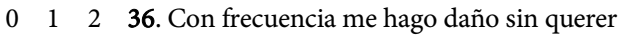

$\begin{array}{llll}0 & 1 & 2 & 37 . \text { Me meto en muchas peleas }\end{array}$

$\begin{array}{llll}0 & 1 & 2 & 38 . \\ 38\end{array}$

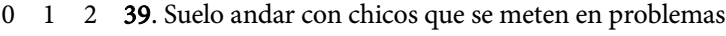

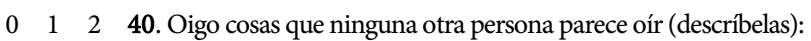

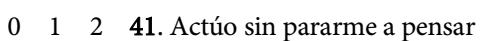

$\begin{array}{llll}0 & 1 & 2 & 42 . \\ \end{array}$

$\begin{array}{llll}0 & 1 & 2 & 43 . \\ 0 & \text { Miento o engaño }\end{array}$

$\begin{array}{llll}0 & 1 & 2 & 44 . \text { Me muerdo las uñas }\end{array}$

$\begin{array}{llll}0 & 1 & 2 & 45 \\ 4\end{array}$

$\begin{array}{lll}0 & 1 & 2\end{array}$ 46. Tengo tics o movimientos nerviosos en algunas partes de mi cuerpo (descríbelos):

$\begin{array}{llll}0 & 1 & 2 & 47 . \text { Tengo pesadillas }\end{array}$

$\begin{array}{llll}0 & 1 & 2 & 48\end{array}$. No les gusto a los demás

$\begin{array}{llll}0 & 1 & 2 & 49 . \\ & & \text { Puedo hace algunas cosas mejor que la mayoría }\end{array}$

$\begin{array}{llll}0 & 1 & 2 & 50 .\end{array}$. Soy demasiado miedoso o ansioso

$\begin{array}{llll}0 & 1 & 2 & 51 . \text { Siento vértigo }\end{array}$

$\begin{array}{llll}0 & 1 & 2 & 52 .\end{array}$ Siento demasiado culpabilidad

$\begin{array}{llll}0 & 1 & 2 & \text { 53. Como demasiado }\end{array}$

$\begin{array}{llll}0 & 1 & 2 & 54 . \text { Me siento muy cansado o agotado }\end{array}$

$\begin{array}{llll}0 & 1 & 2 & 55\end{array}$. Tengo excesivo peso

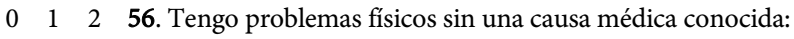

$\begin{array}{llll}0 & 1 & 2 & \text { a) Dolores o achaques }\end{array}$

$\begin{array}{lllll}0 & 1 & 2 & \text { b) Dolores de cabeza }\end{array}$

$\left.\begin{array}{llll}0 & 1 & 2 & c\end{array}\right)$ Náuseas y mareos

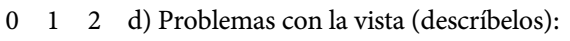

$\begin{array}{llll}0 & 1 & 2 & \text { e) Sarpullidos o erupciones en la piel }\end{array}$

$\begin{array}{llll}0 & 1 & 2 & \text { f) Dolores o calambres en el estómago }\end{array}$

$\begin{array}{llll}0 & 1 & 2 & \text { f) Vómitos }\end{array}$

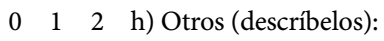




\section{Continued}

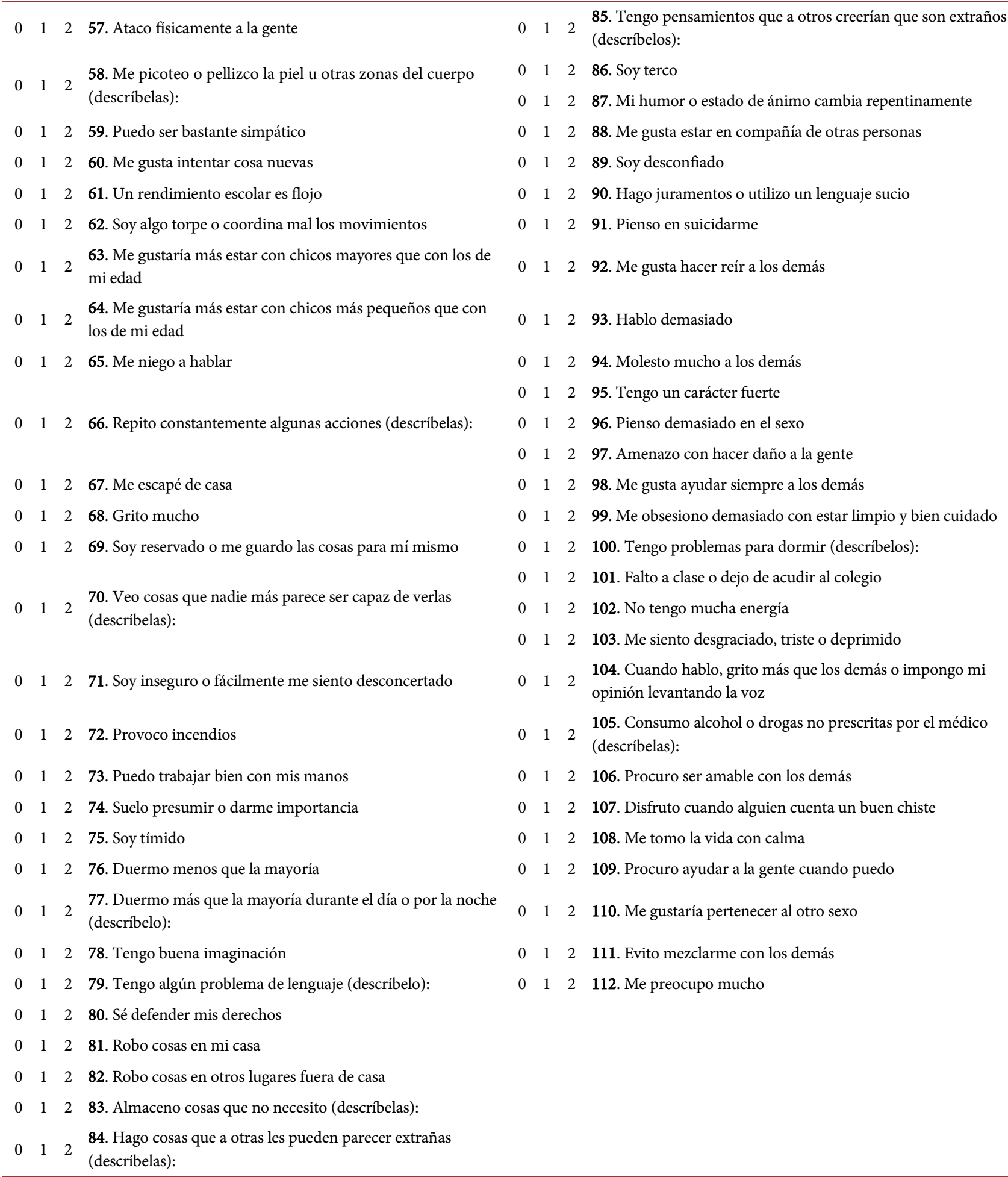

Por favor, escribe a continuación cualquier otra cosa que describa tus sentimientos, conductas o intereses:

ASEGURATE DE QUE HAS CONTESTADO A TODAS LAS PREGUNTAS 